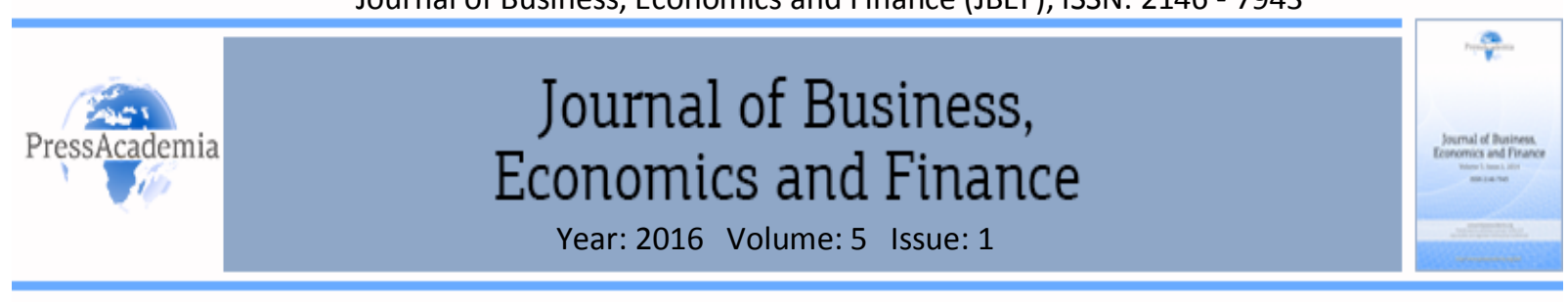

\title{
THE DYNAMICS OF EXCHANGE RATE PASS-THROUGH TO DOMESTIC PRICES IN TURKEY
}

\section{DOI: 10.17261/Pressacademia.2016116552}

\author{
Huseyin Karamelikli ${ }^{1}$, Suna Korkmaz ${ }^{2}$ \\ ${ }^{1}$ Karabuk University. huseyinkaramelikli@karabuk.edu.tr \\ ${ }^{2}$ Bandirma Onyedi Eylul University. skorkmaz@balikesir.edu.tr
}

\begin{abstract}
In an environment where countries have trade relations with each other, prices of domestic goods should vary due to trade. Developing countries in particular import raw materials and semi-manufactured goods from other countries in order to carry out the production process. Final goods are imported for household consumption as well. Exchange rate changes naturally affect domestic prices as well. The effect of exchange rate pass-through on inflation for Turkey was investigated with the NARDL method using the data between January 2003 and November 2015. According to the results of the analysis, an increase in the exchange rate increases the consumer price index. While a decrease in the exchange rate does not have the same reaction, any decrease in the exchange rate would cause prices to increase in the short-run. In addition, domestic product has an asymmetrical and negative relationship with price index in short and long-term according to our analysis. We found that in the short-run both the exchange rate and domestic product are asymmetrically related with the price index where only domestic product asymmetrically affects the consumer price index.
\end{abstract}

Keywords: Exchange rate pass-through, NARDL, domestic prices.

JEL Classification : C51, D51, E31, E50

\section{INTRODUCTION}

The central bank of each country sets certain goals according to country's economic conditions. Monetary policy tools are used in order to achieve these goals. The main goal of the Central Bank of the Republic of Turkey (CBRT) is price stability. In 2002, the inflation targeting was implicitly implemented in Turkey for the first time. Floating exchange rate practice was passed in 2001 when CBRT obtained its independence. The inflation targeting was introduced explicitly in 2006. Inflation is one of the most important macro-economic problems. The functioning order of the economy is disrupted in economies where inflation is present. Inflation disturbs income distribution, leads to reduced savings, negatively affects industrial investments and reduces export rates. Hence, inflation is one of the undesired phenomena in any economy.

One of the greatest difficulties in inflation targeting is effects of import prices and exchange rate shocks on domestic prices. In most developing countries such as Turkey, exchange rates serve as an anchor in terms of pricing. Therefore, when there is an increase in exchange rate, a rise in prices is expected as well. Production is usually dependent on imports in developing countries. In Turkey, imported products seem to constitute the majority especially in the industrial sector. Raw materials and intermediate goods are imported in particular. Imported goods affect domestic prices in two ways. One of them is the exchange rate and the other is import prices. In terms of import, the competition between countries and the structure of internationally traded goods are determining factors. Companies adjust prices of their products depending on the size of the shock from the exchange rate. It is important for an accurate reading of economy to distinguish whether the rise in the price of a domestic product is related to country's currency losing value against U.S. Dollar or a rise in the import price of the product. 
Both internal and external variables could affect the consumer price index. Alongside world markets, domestic production, especially in the case of non-tradable goods, can affect local prices. Therefore in the present study, we examined the industrial production index as a proxy of national production in order to reveal how a rise in the domestic product influences consumer prices. The consumer price index variable was used in order to evaluate the reflection of exchange rate pass-through on domestic prices. The period from 2003, after Turkey implicitly adopted inflation targeting, to the present day was examined in the analysis.

In this study literature will be reviewed as the first step. In the second part, the model will be explained. In this part alongside the long-run model, the NARDL model and its determinants will be described. Empirical results will be presented in the third section. Finally, the forth section contains a summary and the results of this study.

\section{LITERATURE REVIEW}

Hooper and Mann (1989) and Wang and Wu (1996) exchange rate pass-through can be broadly defined as the extent to which a change in the nominal exchange rate induces a change in the import price. Yang (1997) paper studies exchange rate pass-through in U.S. manufacturing industries and its cross-sectional variation. His result shows a negative relationship between import share and exchange rate pass-through. Choudhri and Hakura (2006) have made estimates for 71 countries, covering the period 1979-2000. They exhibit strong evidence of a positive and significant association between the pass-through and the average inflation rate across countries. Mwase (2006) use VAR models and a data set covering the period 1990-2005. He fined that the exchange rate pass-through to inflation declined in the late 1990s. Junior (2007) results show that the response of producer prices inflation to exchange rate changes is higher than that of consumer prices inflation. Devereux and Yetman (2010) paper argues that sticky prices represent a key determinant of exchange rate pass-through. Their model implies that exchange rate pass-through is increasing in average inflation, but at a declining rate. Frimpong and Adam (2010) use VAR model and a data set covering the period 1990M01-2009M02 in Ghana. They find that the exchange rate pass-through to inflation is 'incomplete' and decreasing. Prasertnukul et al. (2010) study examines how the adoption of inflation-targeting influenced exchange rate pass-through and volatility in four Asian countries over the sample period of 1990:01 to 2007:06. They results indicate that inflation targeting caused a decline in exchange rate volatility in all four countries. Kataranova (2010) found pass-through effect has a pronounced asymmetrical character, consumer prices are more respond to the depreciation of the domestic currency, rather than to its appreciation. Beirne and Bijsterbosch (2011) using a five-variate cointegrated VAR for each country, they show that ERPT to consumer prices averages about 0.6 using the cointegrated VAR and 0.5 using the impulse responses. Shintani et al. (2013) use smooth transition autoregressive (STAR) models. Their estimation result suggests that declines in the exchange rate pass-through during the 1980s and 1990s are associated with lowered inflation. Saha and Zhang (2013) have used the VAR model over the period 1990-2011. Their impulse responses tests indicate that exchange rates have less effect in the rising domestic prices in China and India. Peón and Brindis (2014) use Structural Vector Autorregression with exogenous variables (recursive SVAR-X) model. Their results show that the exchange rate pass-through to consumer prices is quite small and fast. Mohammed et al. (2015) investigated the effect of exchange rate passthrough on producer and consumer price index for Algerian economy by examining the period between 2002 and 2011. The empirical findings show that the consumer price increases in response to an appreciate foreign exchange rates but the exchange rate pass-through involves a negligible reaction on producer price index. Cheikh and Louhichi (2016) have used the panel data over the 1992-2012. They point out a strong regimedependence of pass-through to inflation environment, that is, the class of countries with higher inflation rates experiences the higher degree of exchange rate pass-through.

\section{METHODOLOGY}

Campa and Goldberg (2005), Berman et al. (2012), Gopinath and Rigobon (2008) and Goldberg and Knetter (1996) theoretical frameworks and following Çiçek and Boz (2013) our long-run model formulated as follow:

$$
C P I_{t}=\alpha_{0}+\alpha_{1} E R_{t}+\alpha_{2} I N D_{t}+\epsilon_{t}
$$


Where CPI is consumer price index, ER is the US Dollar to Turkish Lira exchange rate and IND represents industrial production index that is used as a proxy of domestic production. The error correction model (ECM) can display a return to long-run equilibrium in the short-run after any diversion from it. The ordinary ECM model can be written as follows:

$$
\Delta C P I_{t}=\beta_{0}+\sum_{j=1}^{p} \beta_{1 j} \Delta C P I_{t-j}+\sum_{j=0}^{q} \beta_{2 j} \Delta E R_{t-j}+\sum_{j=0}^{m} \beta_{3 j} \Delta I N D_{t-j}+\gamma_{1} D U M M Y_{t}+\theta \epsilon_{t-1}+e_{t}
$$

Where $\Delta$ represents the first differences of the variables in model. Here e represents error term in ECM while $\varepsilon$ shows the error-correction term which forms with the OLS residuals series from the long-run cointegrating regression in Equation (1). In regards to the financial crises that occurred in 2008, we added a dummy variable which reflects that months special situation. With the combination of both (1) and (2) numbered equations the following equation would be created:

$$
\begin{gathered}
\Delta C P I_{t}=\psi+\eta_{0} C P I_{t-1}+\eta_{1} E R_{t-1}+\eta_{2} I N D_{t-1}+\sum_{j=1}^{p} \beta_{1 j} \Delta C \mathrm{CPI}_{t-j}+\sum_{j=0}^{q} \beta_{2 j} \Delta E R_{t-j} \\
+\sum_{j=0}^{m} \beta_{3 j} \Delta I N D_{t-j}+\gamma_{1} D U M M Y_{t}+e_{t}
\end{gathered}
$$

With manipulation in error correction model some model parameters has been changed as $\psi=\beta_{0}-$ $\theta \alpha_{0}, \eta_{0}=\theta, \eta_{1}=-\theta \alpha_{1}$ and $\eta_{2}=-\theta \alpha_{2}$. On the other hand $\eta_{0},-\frac{\eta_{1}}{\theta},-\frac{\eta_{2}}{\theta}$ are the long run coefficients of CPI, ER and IND variables, while $\beta_{1}, \beta_{2}$ and $\beta_{3}$ are the short run coefficients of the variables.

The approach that was developed by Schorderet $(2002,2003)$ and Shin et al. $(2014)$ is used in this study to determine the asymmetric pass-through of the exchange rate and the domestic product on the consumer price index. This approach requires that the exchange rate variable be decomposed to positive and negative shocks. Then $E R^{+}$and $E R^{-}$are the partial sums of positive and negative changes in the ER variable. Also $I N D^{+}$and $I N D^{-}$are positive and negative components of the IND variable.

$$
\begin{aligned}
& E R_{t}^{+}=\sum_{i=1}^{t} \Delta E R_{i}^{+}=\sum_{i=1}^{t} \max \left(\Delta E R_{i}, 0\right) ; E R_{t}^{-}=\sum_{i=1}^{t} \Delta E R_{i}^{-}=\sum_{i=1}^{t} \min \left(\Delta E R_{i}, 0\right) \\
& I N D_{t}^{+}=\sum_{i=1}^{t} \Delta I N D_{i}^{+}=\sum_{i=1}^{t} \max \left(\Delta I N D_{i}, 0\right) ; I N D_{t}^{-}=\sum_{i=1}^{t} \Delta I N D_{i}^{-}=\sum_{i=1}^{t} \min \left(\Delta I N D_{i}, 0\right)
\end{aligned}
$$

We use the NARDL (nonlinear autoregressive distributed lag) approach to estimate the asymmetric effect of both the exchange rate and the domestic product on the consumer price index. The NARDL estimation method is derived from the Pesaran et al. (2001) paper by Shin et al. (2014). The nonlinear autoregressive distributed lag model combines the nonlinear the long run relationship with the nonlinear error correction by using the partial sum decompositions. Therefore Equation (1) can be rewritten as follows by considering Equation (4) and (5):

$C P I_{t}=\alpha_{0}+\alpha_{1}^{+} E R_{t}^{+}+\alpha_{1}^{-} E R_{t}^{-}+\alpha_{2}^{+} I N D_{t}^{+}+\alpha_{2}^{-} I N D_{t}^{-}+\epsilon_{t}$

Also by inserting the equation (6) into the equation (2) and taking into account of asymmetry in the short-run that could be rewritten as follow:

$$
\begin{aligned}
& \Delta C P I_{t}=\psi+\eta_{0} C P I_{t-1}+\eta_{1}^{+} E R_{t-1}^{+}+\eta_{1}^{-} E R_{t-1}^{-}+\eta_{2}^{+} I N D_{t-1}^{+}+\eta_{2}^{-} I N D_{t-1}^{-}+\sum_{j=1}^{p} \beta_{1 j} \Delta C P I_{t-j} \\
& +\sum_{j=0}^{q}\left(\beta_{2 j}^{-} \Delta E R_{t-i}^{-}+\beta_{2 j}^{+} \Delta E R_{t-i}^{+}\right)+\sum_{j=0}^{m}\left(\beta_{3 j}^{-} \Delta I N D_{t-i}^{-}+\beta_{3 j}^{+} \Delta I N D_{t-i}^{+}\right)+\gamma_{1} D U M M Y_{t}+e_{t}
\end{aligned}
$$

The parameters of this equation obtained as follow:

$\psi=\beta_{0}-\theta \alpha_{0}, \eta_{0}=\theta, \eta_{1}^{+}=-\theta \alpha_{1}^{+}, \eta_{1}^{-}=-\theta \alpha_{1}^{-}, \eta_{2}^{+}=-\theta \alpha_{2}^{+}, \eta_{2}^{-}=-\theta \alpha_{2}^{-}$ 
The long-run coefficients of nonlinear model are $\eta_{0},-\frac{\eta_{1}^{+}}{\theta},-\frac{\eta_{1}^{-}}{\theta},-\frac{\eta_{2}^{+}}{\theta}$ and $\frac{\eta_{2}^{-}}{\theta}$ which belongs to CPI, $\mathrm{ER}^{+}, \mathrm{ER}^{-}$, IND ${ }^{+}$and IND' respectively.

Following Shin et al. (2014) equation (7) could be divided into long asymmetry and short run symmetry or longrun symmetry and short-run asymmetry.

Similar to the ordinary ARDL model, the long-run cointegration can be determined by t-statistics offered by Banerjee et al. (1998) and Pesaran et al. (2001) suggested F-statistics. Similar to the linear ARDL method, Shin et al. (2014) proposed the bond test to determine the long-run asymmetric cointegration. The bounds test is used to jointly test all lagged level regressors and null hypothesis is defined as $H_{0}: \eta_{0}=\eta_{1}=\eta_{2}=0$ against alternative hypothesis $H_{1}: \eta_{0} \neq 0$ or $\eta_{1} \neq 0$ or $\eta_{2} \neq 0$. When long-run asymmetry is existed in model the null hypothesis should be changed as $H_{0}: \eta_{0}=\eta^{+}{ }_{1}=\eta_{1}^{-}=\eta^{+}{ }_{2}=\eta_{2}^{-}=0$. For checking long-run cointegration, calculated Wald $F$ value would compare with Pesaran et al. (2001) tabulated F values. In addition to long-run cointegration, asymmetry in long-run should be checked by null hypothesis of $H_{0}: \alpha^{+}{ }_{1}=\alpha_{1}^{-}$and $H_{0}: \alpha^{+}{ }_{2}=\alpha_{2}^{-}$. In the case of short-run asymmetry, it should be tested by $H_{0}: \sum_{i=0}^{q} \beta_{2 i}^{+}=\sum_{i=0}^{q} \beta_{2 i}^{-}$and $H_{0}: \sum_{i=0}^{q} \beta_{3 i}^{+}=\sum_{i=0}^{q} \beta_{3 i}^{-}$. In both cases with rejection of a null hypothesis, asymmetric effects statistically should be accepted. Therefore the asymmetric model could be accepted only when a null hypothesis is rejected. By rejecting a null hypothesis of symmetry, asymmetric dynamic multiplier of change of $\mathrm{ER}^{+}, E \mathrm{ER}^{-}, \mathrm{IND}^{+}$and IND could be found respectively. The cumulative dynamic multiplier effects of $\mathrm{ER}^{+}, \mathrm{ER}^{-}, \mathrm{IND}^{+}$and IND' on $\mathrm{CPI}$ can be evaluated respectively as follows:

$$
\begin{aligned}
& m_{h}^{+}=\sum_{i=0}^{h} \frac{\partial C P I_{t+i}}{\partial E R_{t}^{+}} ; m_{h}^{-}=\sum_{i=0}^{h} \frac{\partial C P I_{t+i}}{\partial E R_{t}^{-}} \\
& z_{h}^{+}=\sum_{i=0}^{h} \frac{\partial C P I_{t+i}}{\partial I N D_{t}^{+}} ; z_{h}^{-}=\sum_{i=0}^{h} \frac{\partial C P I_{t+i}}{\partial I N D_{t}^{-}}
\end{aligned}
$$

Note that $\lim _{h \rightarrow \infty} m_{h}^{+}=\alpha_{1}^{+}, \lim _{h \rightarrow \infty} m_{h}^{-}=\alpha_{1}^{-}, \lim _{h \rightarrow \infty} z_{h}^{+}=\alpha_{2}^{+}$and $\quad \lim _{h \rightarrow \infty} z_{h}^{-}=\alpha_{2}^{-}$are $\quad$ valid where $\alpha_{1}^{+}, \alpha_{1}^{-}, \alpha_{2}^{+}$and $\alpha_{2}^{-}$are the asymmetric long-run coefficients. The dynamic multipliers could capture the positive and negative shocks of real exchange rate and domestic product on the consumer price index from an initial equilibrium to the new equilibrium (Shin et al., 2014).

\section{FINDINGS AND DISCUSSIONS}

In this study Turkey's exchange rate pass-through the consumer price index is analyzed. For this purpose we obtained monthly data from January 2003 to November 2015. All data was retrieved from the IMF data service. In this study the industrial production index is used as a proxy of real domestic product. US Dollar equivalence in Turkish Lira is used as exchange rate data as well. All variables were checked for their unit root problem. According to Phillips and Perron (1988) criterion, we found that all of the variables in our model were integrated of the order one.

The full symmetric model (Equation no 7) was estimated by the ordinary least square method with a maximum of 12 lags. Using Akaike Info Criterion (AIC) for selecting the best lag length from 2028 an estimated model led us to choose ARDL $(1,3,9)$. Normality, autocorrelation and heteroscedasticity of the final model made us to be statistically confident that our results are valid. The last step on our estimation is the testing of symmetry for ER and IND variables both in the short-run and the long-run. Symmetry Wald test results are shown in table (1). 
Table 1: Short-run and Long-run Symmetry Tests.

\begin{tabular}{|l|l|l|l|l|}
\hline \multirow{2}{*}{ Variable } & \multicolumn{2}{|l|}{ Short-run } & Long-run & Model II \\
\cline { 2 - 5 } & Model I & Model II & Model I & - \\
\hline ER & $9.625523^{*}$ & $12.81702^{*}$ & $3.251705^{* *}$ & $760.0659^{*}$ \\
\hline IND & $30.90313^{*}$ & $30.37890^{*}$ & $69.17850^{*}$ & 7 \\
\hline
\end{tabular}

Note. ${ }^{*}$ and ${ }^{* *}$ denote significance at $1 \%$ and $10 \%$ level, respectively

The Model I in the Table 1 represents Equation (7) in which all independent variables except the dummy have an asymmetric character. By concentrating on the results of symmetric test on the mentioned variables we can conclude that all hypotheses of symmetry in the short-run were rejected whereas the symmetry hypothesis for ER in the long-run was accepted. Therefore, we cannot treat that variable as asymmetric in the long-run. The model should be rewritten to cover this case and Equation (10) will take the alternative.

$$
\begin{gathered}
\Delta C P I_{t}=\psi+\eta_{0} C P I_{t-1}+\eta_{1} E R_{t-1}+\eta_{2}^{+} I N D_{t-1}^{+}+\eta_{2}^{-} I N D_{t-1}^{-}+\sum_{j=1}^{p} \beta_{1 j} \Delta C P I_{t-j} \\
+\sum_{j=0}^{q}\left(\beta_{2 j}^{-} \Delta E R_{t-i}^{-}+\beta_{2 j}^{+} \Delta E R_{t-i}^{+}\right)+\sum_{j=0}^{m}\left(\beta_{3 j}^{-} \Delta I N D_{t-i}^{-}+\beta_{3 j}^{+} \Delta I N D_{t-i}^{+}\right)+\gamma_{1} D U M M Y_{t}+e_{t}
\end{gathered}
$$

Reestimating of the Model II (Eq 10) with maximum 12 lags surprisingly same lag orders as first model. The results of estimation for both first and second model are in the Table 2.

\begin{tabular}{|c|c|c|}
\hline Variable & Model I & Model II \\
\hline CPI(-1) & $-0.284043^{*}$ & $-0.270706^{*}$ \\
\hline ER N(-1) & $1.525052^{* *}$ & - \\
\hline ER P(-1) & $3.528788^{*}$ & - \\
\hline ER & - & $1.960469 *$ \\
\hline IND N(-1) & $-0.157090^{*}$ & $-0.181448^{*}$ \\
\hline IND $\mathrm{P}(-1)$ & $-0.064524 * *$ & $-0.075285^{*}$ \\
\hline$D(C P I(-1))$ & $0.185682 * *$ & $0.185671^{* *}$ \\
\hline$D(E R \quad N)$ & 1.961235 & 1.398601 \\
\hline$D(E R \quad P)$ & $6.821931^{*}$ & $6.167625^{*}$ \\
\hline$D(E R \quad N(-1))$ & -1.345757 & -2.229815 \\
\hline$D(E R \quad P(-1))$ & 1.215120 & 2.151038 \\
\hline$D(E R \quad N(-2))$ & $-7.619415^{* *}$ & $-7.965968^{*}$ \\
\hline $\mathrm{D}(\mathrm{ER} \quad \mathrm{P}(-2))$ & 1.148737 & 1.649842 \\
\hline$D(E R \quad N(-3))$ & $-6.687265 * *$ & $-7.075626^{* *}$ \\
\hline$D(E R \quad P(-3))$ & $4.025666^{* * *}$ & $4.653639 * *$ \\
\hline $\mathrm{D}($ IND N) & -0.031493 & -0.037155 \\
\hline D(IND P) & $-0.045332 * * *$ & $-0.044147 * * *$ \\
\hline D(IND N(-1)) & $0.131332 *$ & $0.150175^{*}$ \\
\hline D(IND $P(-1))$ & -0.016412 & -0.007648 \\
\hline D(IND N(-2)) & $0.094934 *$ & $0.110177^{*}$ \\
\hline D(IND $P(-2))$ & -0.012099 & -0.002559 \\
\hline D(IND N(-3)) & $0.104834 *$ & $0.120001^{*}$ \\
\hline D(IND $P(-3))$ & $-0.071769 * *$ & $-0.061215^{* *}$ \\
\hline
\end{tabular}

\section{Table 2: Short-run and Long-run Assymetric Models Estimations}




\begin{tabular}{|l|l|l|}
\hline$D(I N D N(-4))$ & $0.063236^{* *}$ & $0.077304^{*}$ \\
\hline$D(I N D P(-4))$ & 0.042457 & $0.055836^{* * *}$ \\
\hline$D(I N D N(-5))$ & $0.076847^{*}$ & $0.088333^{*}$ \\
\hline$D(I N D P(-5))$ & $0.053080^{* * *}$ & $0.064121^{* *}$ \\
\hline$D(I N D N(-6))$ & $0.188329^{*}$ & $0.198895^{*}$ \\
\hline$D(I N D P(-6))$ & 0.038693 & 0.046963 \\
\hline$D(I N D N(-7))$ & $0.154635^{*}$ & $0.160701^{*}$ \\
\hline$D(I N D P(-7))$ & $0.122077^{*}$ & $0.129851^{*}$ \\
\hline$D(I N D N(-8))$ & $0.142780^{*}$ & $0.145138^{*}$ \\
\hline$D(I N D P(-8))$ & -0.035823 & -0.028776 \\
\hline$D(I N D N(-9))$ & $0.070252^{* *}$ & $0.068173^{* *}$ \\
\hline$D(I N D P(-9))$ & $-0.082423^{*}$ & $-0.075266 *$ \\
\hline$C$ & $28.79100^{*}$ & $24.07646^{*}$ \\
\hline DUMMY & $-1.560251^{*}$ & $-1.186554^{*}$ \\
\hline Heteroskedasticity F & 1.003745 & 0.959103 \\
\hline Jarque-Bera & $5.891053^{* * *}$ & 2.563189 \\
\hline Bound F & 11.36004 & 12.14496 \\
\hline R2 & 0.694156 & 0.685151 \\
\hline F-statistic & $7.003454^{*}$ & $6.976399^{*}$ \\
\hline
\end{tabular}

Note. ${ }^{*}, * *$ and $* * *$ denote significance at $1 \%, 5 \%$ and $10 \%$ level, respectively

Testing for Normality, Heteroscedasticity, autocorrelation and CUSUM stability test for the second model shows that there is not any statistical problem in our estimation. Looking for long-run coefficients of the exchange rate and domestic production reveals that both positive and negative components of domestic production have a negative effect on the consumer price index. Therefore any increase in domestic production will cause a significant decrease in the price index where a decrease in domestic production will push the price index to be increased as well. Our estimation displays that in the long-run effects of increase and decrease in domestic production are not same. Also we found that the exchange rate effects are symmetric and negatively related to price index in the long-run. 
Figure 1: Short-run Dynamics of Exchange Rate

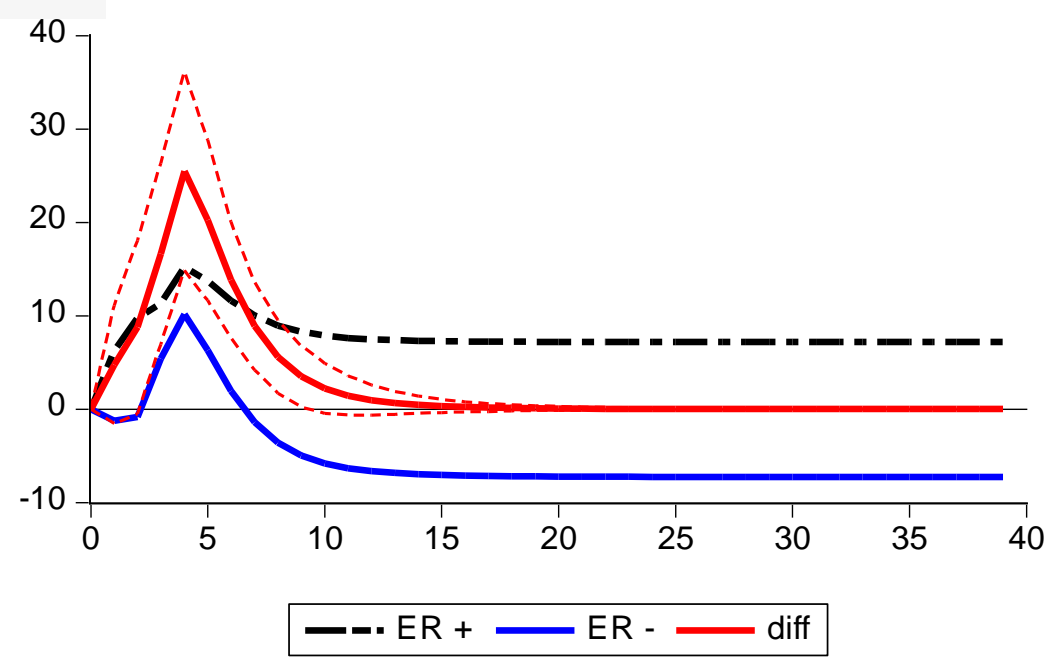

Figure 2: Short-run Dynamics of Domestic Product

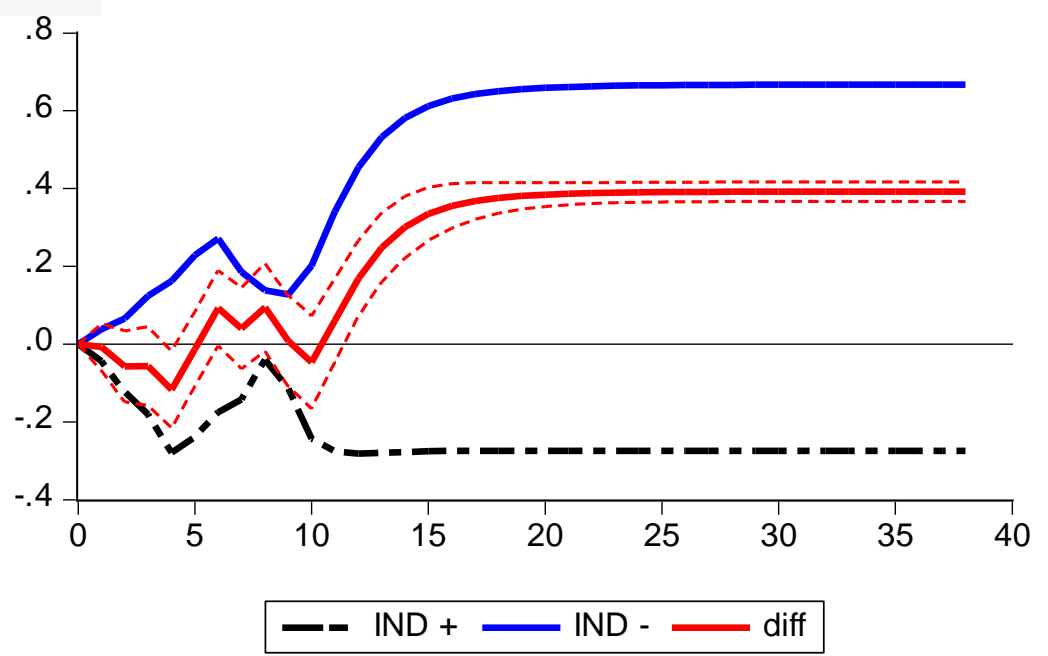

Figure (1) displays the short-run dynamics of the exchange rate. Any increase on the exchange rate has a positive effect on consumer prices because firms could adjust their prices due to increases of imported goods in domestic prices, whereas a decreasing in the exchange rate could have the inverse effect. In the short-run prices would be increased despite the decreasing of exchange rates. In the case of oligopoly, firms are able to adjust their prices due to market conditions. Therefore, an increase in the exchange rate should be reflected in commodity prices. This situation puts inflationary pressure on the market and which will reach its maximum level in four months. After that point the decrease of demand due to the increasing price of goods would cause a diminishing of the prices that jumped so high since the fifth month. Any decreasing in the exchange rate has a totally different effect. Because of price rigidity, sellers of imported goods would not reduce their prices immediately, while exporters would be faced with sudden loss because of the absence of price changing power in global markets. Then, in order to provide compensation for loses in the global market exporter firms may 
prefer local markets with high profit margins in the short-run. Therefore, despite a decrease in the exchange rate, the consumer price index would be increased in the short-run. Along with the case of the increase in the exchange rate, in the case of decreasing of exchange rate the five month mark is the starting point of long-run adjustment.

Figure 2 displays the effects of increases and decreases in the domestic production in the short-run. We can see that the long-run positive effect of decreasing is greater than the negative effects of increasing in domestic production. We can conclude that devastative effect of decrease in national product in long-run is very higher than an amendatory when increasing in national product occurred. It can be summarized that negative shocks have more pressure on general prices in comparison to positive shocks in long-run. Therefore any decrease in production would cause structural disruptive effect on economic system especially on inflationary expectations.

\section{CONCLUSION}

It was analyzed with the NARDL method whether exchange rate pass-through had any effect on consumer price index. The period from January 2003 to November 2015 was examined. It was found that an increase in the exchange rate increased the consumer price index. Because price increases in imported goods are reflected by companies in prices of their own products, which inducing the rise in inflation. In addition, it was found that exchange rate influences had a symmetrical and positive relationship with price index in long-term. We can see that long-run positive effect of decreasing is greater than negative effects of increasing in domestic production. The finding that exchange rate would affect consumer price at positive direction is consistent with findings of Choudhri and Hakura (2006), Devereux and Yetman (2010), Shintani et al. (2013), Mohammed et al. (2015), Cheikh and Louhichi (2016) in the literature. However, it conflicts with findings of Mwase (2006), Frimpong and Adam (2010), Saha and Zhang (2013), Peón and Brindis (2014).

Exchange rate pass-through is of great importance for countries implementing inflation targeting. Exchange rate pass-through seems to be low in countries practicing floating exchange rate policy. However, the completion of pass-through takes time in cases where exchange rate shocks have a certain direction and are continuous. Intractable exchange rate shocks have greater influence on inflation. Especially in developing countries, increases in exchange rates are reflected positively on domestic prices. The increase in the exchange rate affects the industrial sector as well. Because raw materials and semi-manufactured goods of finished products manufactured by the industrial sector in Turkey are imported from overseas, an increase in the exchange rate increases prices of imported products as well, thus a change in domestic production index occurs. Then, one of the possible measures to reduce the effect of exchange rate pass-through is to produce goods with higher added-value. Another factor that will reduce exchange rate pass-through is the monetary policy adopted by the Central Bank. The capital will flow to developing countries for short-term due to difference in interest rates between developed countries and developing countries. As a result, the domestic currency will gain value. This will lead to deterioration in the trade balance. For this reason, the CBRT utilizes monetary policy tools such as interest rate corridor and reserve option mechanism in order to reduce the pressure on Turkish Lira created by rapid capital flows.

In this study we found that the short-run asymmetric relation is prevailing for both the exchange rate and domestic product, while only domestic product has long-run asymmetric relation with the consumer price index. Also, we found that in the short-run both the increase and decrease in the exchange rate would affect consumer prices in a positive direction. However, in the long-run each of the positive or negative decompositions of the exchange rate would affect price in similar directions. Therefore, monetary policy makers of Turkey have to be vigilant about volatilities in the exchange rate. The most important finding of this study is about the strong effect of negative changes in domestic product on local prices. This means that any negative shocks in the domestic product would be interpreted as future economic crises and put heavy pressure on prices. Therefore economic authorities have to concentrate on real sector production and keep it on a rapidly increasing path of production. 


\section{REFERENCES}

Banerjee, A., Dolado, J., \& Mestre, R. (1998). Error-correction Mechanism Tests for Cointegration in a Single-equation Framework. Journal of Time Series Analysis, 19 (3), 267-283. http://doi.org/10.1111/1467-9892.00091.

Beirne, J. and Bijsterbosch, M. (2011), "Exchange Rate Pass-through in Central and Eastern European EU Member States", Journal of Policy Modeling, 33 (2), 241-254.

Berman, N., Martin, P., \& Mayer, T. (2012). How do Different Exporters React to Exchange Rate Changes? The Quarterly Journal of Economics, 127 (1), 437-492. http://doi.org/10.1093/qje/qjr057.

Campa, J. M., \& Goldberg, L. S. (2005). Exchange Rate Pass-Through into Import Prices. Review of Economics and Statistics, 87 (4), $679-690$. http://doi.org/10.1162/003465305775098189.

Cheikh, N. B. and Louhichi, W., (2016), "Revisiting the Role of Inflation Environment in Exchange Rate Pass-through: A Panel Threshold Approach", Economic Modelling, 52, 233-238.

Choudhri, E. U. and Hakura, D. S., (2006), “Exchange Rate Pass-through to Domestic Prices: Does the Inflationary Environment Matter?”, Journal of International Money and Finance, 25 (4), 614-639.

Çiçek, S., \& Boz, Ç. (2013). A New Test of Exchange Rate Pass-through in a Small Open Economy: Evidence from Asymmetric ARDL Bounds Approach. Iktisat işletme ve Finans, 28 (333), 43-64. http://doi.org/10.3848/iif.2013.333.3840.

Devereux, M. B. and Yetman, J. (2010), "Price Adjustment and Exchange Rate Pass-Through", Journal of International Money and Finance, 29 (1), 181-200.

Frimpong, S. and Adam, A. M., (2010), “Exchange Rate Pass-Through in Ghana”, International Business Research, 3 (2), $186-192$.

Goldberg, P., \& Knetter, M. (1996). Goods Prices and Exchange Rates: What Have We Learned? (NBER Working Paper No. 5862). Cambridge, MA. Retrieved from http://www.nber.org/papers/w5862.pdf.

Gopinath, G., \& Rigobon, R. (2008). Sticky Borders. Quarterly Journal of Economics, 123 (2), 531-575.

http://doi.org/10.1162/qjec.2008.123.2.531.

Hooper, P. and Mann, C. L. (1989), "Exchange Rate Pass-through in the 1980s: The Case of U.S. Imports of Manufactures", Brookings Papers on Economic Activity, No. 1, 297-337.

Junior, R.P.N. (2007)," Inflation Targeting and Exchange Rate Pass-Through", Econ. Aplic, 11 (2), 189-208.

Kataranova, M. (2010), "The Relationship Between the Exchange Rate and Inflation in Russia", Problems of Economic Transition, 53 (3), 45 68.

Mohammed, K. S., Bendob, A., Djediden, L.and Mebsout, H., (2015), "Exchange Rate Pass - Through in Algeria”, Mediterranean Journal of Social Sciences, 6 (2), 195-201.

Mwase, N. (2006), “Empirical Investigation of the Exchange Rate Pass-Through to Inflation in Tanzania”, IMF Working Paper, WP/06/150.

Peón, S.B.G. and Brindis, M.A.R., (2014), "Analyzing the Exchange Rate Pass-through in Mexico: Evidence Post Inflation Targeting Implementation", Ensayos sobre Política Económica, 32 (74), 18-35.

Pesaran, M. H., Shin, Y., \& Smith, R. J. (2001). Bounds Testing Approaches to the Analysis of Level Relationships. Journal of Applied Econometrics, 16 (3), 289-326. http://doi.org/10.1002/jae.616.

Phillips, P. C. B., \& Perron, P. (1988). Testing for a Unit Root in Time Series Regression. Biometrika, 75 (2), $335-346$.

http://doi.org/10.1093/biomet/75.2.335.

Prasertnukul, W., Kim, D. And Kakinaka, M. (2010), “Exchange Rates, Price Levels, and Inflation Targeting: Evidence from Asian Countries”, Japan and World Economy, 22 (3), 173-182.

Saha, S. and Zhang, Z. (2013), "Do Exchange Rates Affect Consumer Prices? A Comparative Analysis for Australia, China and India", Mathematics and Computers in Simulation, 93, 128-138.

Schorderet, Y. (2002). A Nonlinear Generalization of Cointegration: A Note on Hidden Cointegration (No. 2002.03). Genève. Retrieved from http://www.unige.ch/ses/metri/

Schorderet, Y. (2003). Asymmetric Cointegration (No. 2003.01). Cahiers du département d'économétrie, Faculté des sciences économiques et sociales, Université de Genève.

Shin, Y., Yu, B., \& Greenwood-nimmo, M. (2014). Modelling Asymmetric Cointegration and Dynamic Multipliers in a Nonlinear ARDL Framework. In R. C. Sickles \& W. C. Horrace (Eds.), Festschrift in Honor of Peter Schmidt Econometric Methods and Applications (pp. 281314). http://doi.org/10.1007/978-1-4899-8008-3.

Shintani, M., Terada-Hagiwara, A. and Yabu, T. (2013), "Exchange Rate Pass-through and Inflation: A Nonlinear Time Series Analysis", Journal of International Money and Finance, 32 , 512-527. 
Wang, K-L and Wu, C-S., (1996), "Exchange Rate Pass-through and Industry Characteristics: The Case of Taiwan's Exports of Midstream Petrochemical Products", NBER Working Paper, No. 5749, 1-28.

Yang, J. (1997), "Exchange Rate Pass-Through in U.S. Manufacturing Industries", The Review of Economics and Statistics, 79 (1), 95-104. 